\title{
The Importance of Emotional Intelligence in Interpersonal Relationships: A Study on Pilots in the Context of Daniel Goleman's Emotional Intelligence Model
}

\author{
Kişilerarası İlişkilerde Duygusal Zekânin Önemi: Daniel Goleman 'in Duygusal Zekâ Modeli \\ Bağlamında Pilotlar Üzerine Bir Araştirma
}

\author{
EInaz SAFARLI \\ seferlielnaz@gmail.com \\ https://orcid.org/0000-0003-1056-9906
}

\author{
Received \\ Revised \\ Accepted \\ : 02.05 .2021 \\ :06.12.2021 \\ Type of Article : Research
}

\begin{abstract}
Keywords:

Emotional

Intelligence,

Interpersonal Communication,

Pilots

The purpose of the current study is to test the relationship between the emotional intelligence levels of pilots and the dimensions of interpersonal relationships. The research consists of three parts. In the first part, the concept of interpersonal communication, in the second part, the concept of emotional intelligence, in the third part, the identification, evaluation, use and regulation of one's own and others' emotions and how interpersonal relationship dimensions change according to demographic factors are discussed. In this study, a survey was conducted on pilots. The analysis of the data was conducted with the SPSS 21.0 (Statistical Package for Social Sciences) program package. After a comprehensive literature review, it was tried to determine the scales that could measure the variables used in the best way and it was decided to use the scales whose validity and reliability was tested with different studies in the international literature. In addition, 7 questions were developed to determine the demographic characteristics of the pilots. The research model used is the descriptive research model because it was aimed to reveal the current situation in detail. When the analysis results were examined, it was understood that there was a significant relationship between the emotional intelligence levels of the pilots and the dimensions of interpersonal relations.
\end{abstract}

\section{ÖZET}

Bu araştırmanın amacı; pilotların duygusal zekâ düzeyleri ile kişilerarası ilişsi boyutları arasındaki ilişkiyi test etmektir. Araştırma üç bölümden oluşmaktadır. Birinci bölümde kişilerarası iletişim kavramından, ikinci

Anahtar Kelimeler:

Duygusal Zekâ,

Kişilerarası İlişki,

Pilotlar bölümde duygusal zekâ kavramından detaylı bahsedilmiş, üçüncü bölümde ise pilotların kendi ve başkalarının duygularını tanımlaması, değerlendirmesi, kullanması ve yönetmesi ile kişilerarası ilişki boyutlarının demografik faktörlere göre nasıl değiştiği analiz edilmiştir. Bu araştırmada pilotlar üzerinde anket çalışması yapılmıştır. Verilerin analizi SPSS 21.0 (Statistical Package for Social Sciences) paket programı ile analiz edildi. Araştırmaya yönelik kapsamlı bir yazın taramasından sonra kullanılan değişkenleri en iyi biçimde ölçebilecek ölçekler belirlenmeye çalışılmış ve uluslararası yazında geçerliliği ve güvenilirliği farklı çalışmalarla test edilmiş ölçeklerin kullanılmasına karar verilmiştir. Buna ek olarak çalışanların demografik özelliklerini tespit etmek amacıla 7 soru gelişstirilmiştir. Araştırmanın modeli tanımlayıcı araştırma özelliğindedir. Araştırma modeli olarak tanımlayıcı araştırmalarda değişkenler kullanılarak mevcut durumun ayrıntılı bir şekilde ortaya çıkarılması amaçlanmıştır. Analiz sonuçları incelendiğinde Pilotların duygusal zekâa düzeyleri ile kişilerarası ilişkiler boyutu arasında anlamlı bir ilişsi olduğu tespit edilmiştir. 


\section{INTRODUCTION}

Emotional intelligence can be developed over time. If an individual has a high level of emotional intelligence, he/she can not only understand and control his/her own emotions but also have a significant emotional impact on other people. In this context, businesses can provide significant improvements in interpersonal relationships by improving their employees' emotional intelligence.

In the current study, emotional intelligence perceptions were examined with 5 different emotional intelligence dimensions on pilots. To this end, an emotional intelligence scale widely used in the literature was used. There are a total of 30 items on this scale. The original alpha coefficient of the emotional intelligence scale was found to be 0.84 . In the current study, the Scale of Interpersonal Relationship Dimensions was also used. This scale consists of 4 sub-dimensions and 32 items. The original Alpha coefficients of the scale were calculated to be ranging from 0.78 to 0.84 . In the analysis of the collected data, the SPSS 21.0 (Statistical Package for Social Sciences) program package was used. One-way variance analysis, independent samples t-test and Pearson correlation analysis were employed to analyse the data.

In the study, the relationship between emotional intelligence and interpersonal relationship was examined. In this context, it was also determined how the relationship between pilots' identification, evaluation, use and regulation of their own and others' emotions and interpersonal relationship varies depending on demographic factors. The study was conducted on 215 pilots. The great majority of the participating pilots are males and first officers. Moreover, $45.1 \%$ of the participants are in the age group of $28-34$ and $33.5 \%$ are university graduates (from the department of pilotage and related departments). In addition, $58.6 \%$ of the participants are single and $55.3 \%$ have a professional experience of 0-6 years.

As a result of the study, a significant correlation was found between the emotional intelligence levels of the pilots and their interpersonal relationships. In light of the results of the study, some suggestions were made for further research. Due to the limited amount of research conducted in our country on interpersonal relationships, which have been more strongly emphasized in the literature in recent years, it is thought that it is necessary to conduct research on this important subject. In addition, it is important to carry out a large-scale research on the issue of emotional intelligence and how important it is in human life. Therefore, there is a need for future studies to be conducted in these areas with different and larger samples.

\section{CONCEPTUAL FRAMEWORK}

\subsection{Daniel Goleman Model}

Goleman's model, based on Mayer and Salovey's model, has shown that emotional intelligence consists of abilities such as knowing one's own emotions, recognizing emotions in others, motivating oneself and regulating emotions. Goleman divided the Emotional Intelligence Model into two groups. These are personal competence and social competence.

\section{a) Personal Competence:}

$\checkmark$ Self-awareness means knowing one's own emotions and feelings; that is, emotional self-awareness. This self-awareness is made up of one's confidence in his/her own abilities and skills.

$\checkmark$ Self-regulation is the ability to direct oneself to change by being open to new ideas and information, without ignoring what they know correctly, maintaining their honesty.

$\checkmark$ Motivation refers to the strong desire to achieve and to go further by trying to accomplish his/her personal goals or institutional goals and not to miss opportunities.

\section{$\checkmark$ b) Social Competence:}

$\checkmark$ Empathy consists of abilities such as being able to put oneself in the shoes of others, to understand their needs, to help them in their difficult times, to be able to consciously guide the other without escaping from any responsibility.

$\checkmark$ Social skills include skills such as being able to listen to the other person by establishing open communication, establishing and managing communication in such a way as to serve the purpose, 
SAFARLI, Elnaz - The Importance of Emotional Intelligence in Interpersonal Relationships: A Study on Pilots in the Context of Daniel Goleman's Emotional Intelligence Model

initiating change and controlling conflicts, working with others and guiding them in line with the goals (Yan, 2008, p. 20).

\subsection{The Importance of Emotional Intelligence in Business Life}

Emotional intelligence is a combination of the words emotion and intelligence that have opposite meanings when used separately. When we think of emotional intelligence in business life, at first glance, it is always thought that emotions should not interfere with business. The concepts of emotion and business are kept separate, and it is generally predicted that the effects of emotions on business could be harmful.

The following six principles of emotion are important in emotional intelligence:

1. Emotions always carry information.

2. Even if we try to remove emotions from our lives, this will not be possible because only with our emotions and feelings, we can be humans (Scientifically speaking, the oldest centre of the brain is the emotional brain).

3. We can try to suppress emotions but we cannot destroy them.

4. It is necessary to cooperate with emotions to make the right decisions.

5. Emotions imitate what makes sense.

6. Feelings such as fear, happiness and rejoicing are universal. Feelings are also original (Caruso \& Salovey, 2007, p. 40).

In order to measure emotional intelligence, we can ask the question "How's your mood right now?" If the answer to this question is that "I am wrong about it" then you can think "I should correct my mistake". Such feelings as the following can emerge in such cases; "I should correct the mistake, I do not know, so I should learn, I know and I should put what I know into practice, I have difficulties but I should try to put up with, I am pessimistic but I should try to be optimistic and positive, I am nervous so I should delay the solution" (Tarhan, 2017, p. 203).

People who cannot hide their emotions in business life are not accepted because emotions are seen as the source of many mistakes and problems. In contrast, as long as we try to hide our feelings and do not understand the reason, the same feelings will capture our inner world from time to time. "Emotions are the remains of 300 million years ago (when emotions were needed for our species to survive)" (Caruso \& Salovey, 2007, p. 9).

Emotional Intelligence in Management was developed in the late 1980s by John Mayer and Peter Salovey, with an approach based on the competence to use emotional abilities. This approach is called emotional intelligence. This method consists of four different skills that follow a hierarchical order.

Ensuring self-control by being ready and conscious of every positive and negative emotion is one of the most important things taught by emotional intelligence. In a national survey, a survey question was asked the managers about what qualifications they look for in their newly recruited employees. In line with the results of the survey, it was revealed that technical skills and experiences do not matter much in the first stage, and learning skill is the most important feature sought in a new employee, followed by the qualifications given below;

- Developed listening and verbal communication skills,

- Being able to adapt to the environment and cope with problems in working life,

- Self-regulation, self-confidence and motivation, continuous self-improvement,

- Effective communication, solution-orientedness and cooperation in the work environment,

- The ability to be effective with their communication and knowledge, to be the leader of their own business and to manage it well.

In addition to this study, similar results were obtained in another study conducted on MBA graduates hired by companies. The three skills that managers want to see in their employees are communication skills, interpersonal skills, and taking initiative. A study was conducted on the efficiency of emotional intelligence in business life with the participation of 250 senior executives and it was found that the majority of the participants think "I should use my head, not my heart". It was revealed that some of the managers were afraid to act out of emotions. Some stated that it is not possible to understand the thoughts and feelings of the employees and that trying to manage them considering their feelings would be really difficult (Goleman, 2003, p. 192). 
The setbacks and problems in business life, after a while, may force employees to look for better working conditions and to prevent this, managers should assume important responsibilities. It is of utmost importance to bring employees together sometimes to keep their motivation high, to take care of them and to encourage them with rewards to ensure healthy competition as stated by Goleman "Market forces that reshape business life emphasize emotional intelligence as the main factor in business success and state that toxic emotions put our physical health at risk as much as smoking, and that emotional balance plays an important role in protecting our health and well-being" (Goleman, 2003, p. 191). Because we have an emotional nature due to our creation, our first reaction will be emotional. But it's in our hands to take control of these emotions (Bradberry \& Greaves, 2017, p. 28). As stated by Aristotle, it is important "to be angry with the right person, to the right extent, for the correct reason and in the correct way" in business life.

\section{METHOD}

In this section of the study, first, the purpose and significance of the study will be explained, then the scope and limits of the study will be drawn, the method, dimensions, scales and hypotheses of the study will be discussed and finally, the findings of the study will be presented.

\subsection{Significance and Purpose of the Study}

Emotional intelligence can be developed over time. If an individual has a high level of emotional intelligence, he/she can not only understand and control their own emotions but also have a significant emotional impact on other people. In this context, businesses can provide significant improvements on interpersonal relationships by improving their employees' emotional intelligence. The purpose of the current study is to test the relationship between the emotional intelligence levels of pilots and their interpersonal relationship dimensions. It will also be determined how the relationship between pilots' identification, evaluation, use and regulation of their own and others' emotions and interpersonal relationship dimensions varies depending on demographic factors.

\subsection{Scope and Limits of the Study}

The population of the study is comprised of individuals working as pilots in Turkey. The data of the study were collected within a two-month period covering October 2020 and November 2020 by using a questionnaire. A total of 230 pilots were administered the questionnaire and 217 of them were returned. Two of these questionnaires were discarded as they were incomplete.

\subsection{Research Method}

In the current study, the questionnaire method was used to collect data. After a comprehensive literature review, it was tried to determine the scales that could measure the variables used in the best way and it was decided to use the scales whose validity and reliability was tested with different studies in the international literature. In addition, 7 questions were developed to elicit demographic features of the participants. These seven questions were designed to elicit data about the participants' demographic features such as gender, marital status, income level, position, education level, etc.

The emotional Intelligence Assessment Scale was developed in 1999 by Nick Hall with the aim of assessing the level of emotional intelligence and adapted to Turkish Ergin (2000: 1-100) and used in many studies in Turkey. The scale consisted of 30 items have five sub-dimensions; "Emotional Awareness" (items 1, 2, 4, 17, 19, 25), "Regulating One's Own Emotions" (items 3, 7, 8, 10, 18, 30), "Internal Motivation" (items 5, 6, 13, 14, 16, 22), "Empathy" (items 9, 11, 20, 21, 23, 28) and "Regulating Other's Emotions" (items 12, 15, 24, 26, 27, 29) (Ergin, 2000). The items in the scale designed in the Likert type are scored as follows: "strongly disagree" (1 point), "partially disagree" ( 2 points), "a little disagree" ( 3 points), "a little agree" (4 points), "partially agree" (5 points), "strongly agree" (6 points).

The Scale of Interpersonal Relationship Dimensions was developed by İmamoğlu (2008). The scale consisted of 32 items have four sub-dimensions called "Approval Dependency" (items 2, 4, 7, 11, 17, 21, 26, 28, 30, 32, 33, 36, 40, 41, 45), "Empathy" (items 18, 27, 34, 37, 39, 42, 44, 48, 51) "Trust in Others" (items 1, 5, 14, 20, 22, 23, 24, 29, 31, 35, 38, 43, 47, 50, 53), "Emotional Awareness" (items 3, 6, 8, 9, 10, 12, 13, 15, 16, 19, 25, 46, 49, 52). Items are designed in the 5-point Likert scale. The items are followed by the question "To what extent does it describe you?" and the response options are; "Exactly Describes", "Moderately Describes", "Partially Describes", "Very Little Describes" and "Not Describes At All". 
SAFARLI, Elnaz - The Importance of Emotional Intelligence in Interpersonal Relationships: A Study on Pilots in the Context of Daniel Goleman's Emotional Intelligence Model

\subsection{Variables of the Study}

In the current study, emotional intelligence perceptions were examined within 5 different emotional intelligence dimensions on pilots. To this end, an emotional intelligence scale widely used in the literature was used. There are a total of 30 items on this scale. The original alpha coefficient of the emotional intelligence scale was found to be 0.84 . In addition to this scale, the Scale of Interpersonal Relationship Dimensions was also used in the current study and this scale consists of 4 different sub-dimensions and 32 items. The original alpha coefficients of this scale were found to be ranging from 0.78 to 0.84 .

\subsection{Research Model}

The current study is a descriptive study. Descriptive research aims to reveal the existing state in a detailed manner by using variables. In the current study, it is aimed to measure the relationship between the pilots' demographic features and levels of emotional intelligence, the relationship between the demographic features and interpersonal relationship dimensions and the relationship between the levels of emotional intelligence and the interpersonal relationship dimensions. The research model developed for this purpose is given below.
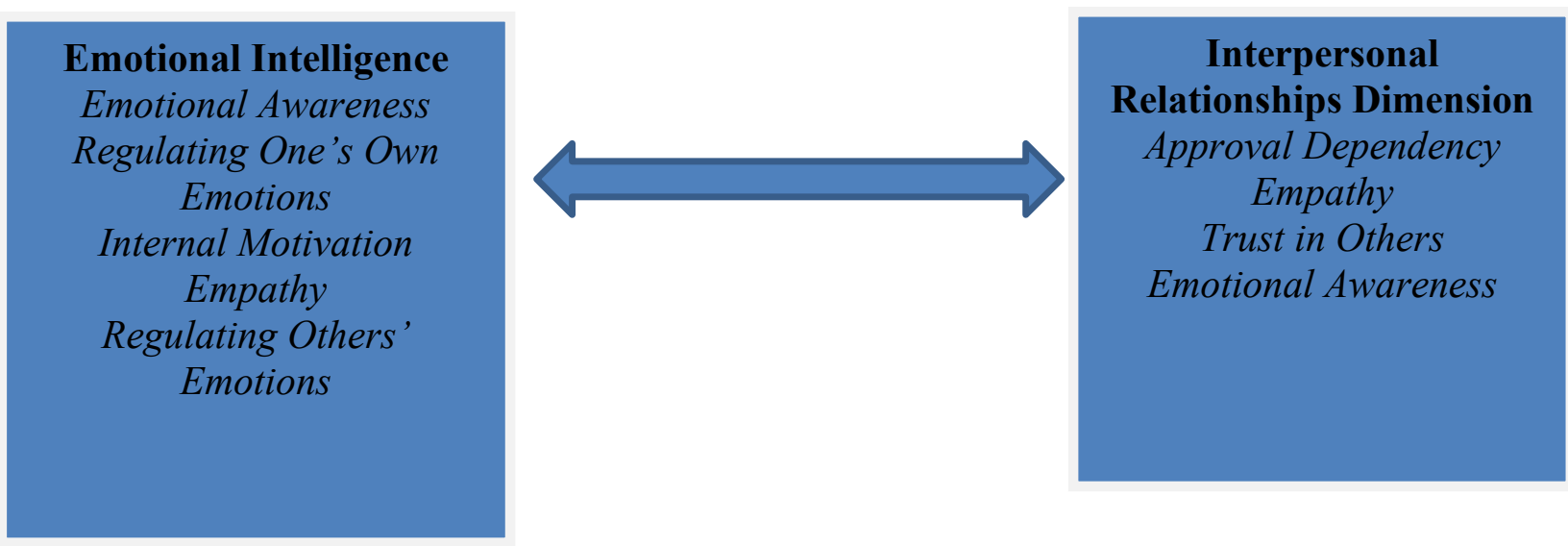

Figure 1. Research Model

\subsection{Research Hypotheses}

In the current study, the relationship between emotional intelligence and interpersonal relationship dimensions will be determined. In this context, the hypotheses developed in the current study are given below:

$\mathrm{H}_{1}$ : The pilots' level of emotional intelligence varies significantly depending on demographic variables.

$\mathrm{H}_{2}$ : The pilots' interpersonal relationship dimensions vary significantly depending on demographic variables.

$\mathrm{H}_{3}$ : There is a significant relationship between the pilots' level of emotional intelligence and interpersonal relationship dimensions.

\section{FINDINGS}

In this section of the study, the participants' demographic and professional information is presented in the form of frequencies and percentages.

Table 1. Participations' Demographic Features

\begin{tabular}{|c|c|c|c|}
\hline & Features & $\mathbf{N}$ & $\mathbf{\%}$ \\
\hline \multirow{2}{*}{ Gender } & Female & 59 & 27.4 \\
\cline { 2 - 4 } & Male & 156 & 72.6 \\
\hline \multirow{3}{*}{ Age } & $21-28$ & 70 & 32.6 \\
\cline { 2 - 4 } & $28-34$ & 97 & 45.1 \\
\cline { 2 - 4 } & 35 and older & 48 & 22.3 \\
\hline Marital Status & Married & 89 & 41.4 \\
\hline
\end{tabular}




\begin{tabular}{|c|c|c|c|}
\hline & Single & 126 & 58.6 \\
\hline \multirow{4}{*}{ Education Level } & High School (Science High School) & 41 & 19.1 \\
\hline & High School (Social Sciences High School) & 50 & 23.3 \\
\hline & $\begin{array}{l}\text { University (Pilotage and related } \\
\text { departments) }\end{array}$ & 72 & 33.5 \\
\hline & University (other departments) & 52 & 24.2 \\
\hline \multirow{3}{*}{ Length of Service } & $0-6$ years & 119 & 55.3 \\
\hline & $7-12$ years & 62 & 28.8 \\
\hline & 13 and longer & 34 & 15.8 \\
\hline \multirow{3}{*}{ Where You Work } & Domestic Airlines & 80 & 37.2 \\
\hline & International Airlines & 49 & 22.8 \\
\hline & Others (flying school or other organizations) & 86 & 40.0 \\
\hline \multirow{2}{*}{ Position } & Chief Pilot (Pilot in Command) & 75 & 34.9 \\
\hline & First Officer & 140 & 65.1 \\
\hline
\end{tabular}

The demographic features of the pilots participating in the current study are given in Table 1 . When the results are examined, it is seen that the majority of the participants are males and first officers. Moreover, $45.1 \%$ of the participants are in the age group of 28-34 and 33.5\% are university graduates (from the department of pilotage and related departments). In addition, $58.6 \%$ of the participants are single and $55.3 \%$ have a professional experience of $0-6$ years.

Table 2. Reliability of the Scales and their Sub-dimensions

\begin{tabular}{|l|c|c|}
\hline Scales and Sub-dimensions & Item Number & $\begin{array}{c}\text { Cronbach's } \\
\text { Alpha }\end{array}$ \\
\hline Emotional Intelligence Scale & $\mathbf{1 - 3 0}$ & $\mathbf{9 8 0}$ \\
\hline Emotional Awareness & $1-2-4-17-19-25$ & .912 \\
\hline $\begin{array}{l}\text { Regulating One's Own } \\
\text { Emotions }\end{array}$ & $3-7-8-10-18-30$ & .918 \\
\hline Internal Motivation & $5-6-13-14-16-22$ & .902 \\
\hline Empathy & $9-11-20-21-23-28$ & .879 \\
\hline Regulating Others' Emotions & $12-15-24-26-27-29$ & .931 \\
\hline $\begin{array}{l}\text { Scale of Interpersonal } \\
\text { Relationship Dimensions }\end{array}$ & $\mathbf{1 - 3 2}$ & $\mathbf{8 1 8}$ \\
\hline Approval Dependency & $2,4,7,11,17,21,26,28,30,32,33,36,40$, & .801 \\
\hline Empathy & 41,45 & .811 \\
\hline Trust in Others & $18,27,34,37,39,42,44,48,51$ & .816 \\
\hline Emotional Awareness & $1,5,14,20,22,23,24,29,31,35,38,43$, & .821 \\
\hline
\end{tabular}

In Table 2, the reliability scores obtained for the Interpersonal Relationship Dimensions and Emotional Intelligence Scales are presented. The validity of a scale on the other hand is related to the extent to which the scale can measure the construct it intends to measure. There is no certain coefficient that can be used to evaluate the validity. Therefore, the validity test is conducted with theoretical analyses. As can be seen in Table 2, the sub- 
SAFARLI, Elnaz - The Importance of Emotional Intelligence in Interpersonal Relationships: A Study on Pilots in the Context of Daniel Goleman's Emotional Intelligence Model

dimensions of emotional intelligence and interpersonal relationship dimensions have high-reliability scores $(>.80)$.

Table 3. Normality Test for the Scales and their Sub-dimensions

\begin{tabular}{|l|c|c|c|c|c|}
\hline Scales and Sub-dimensions & \multicolumn{2}{|l|}{ Mean } & $\begin{array}{l}\text { Standard } \\
\text { Deviation }\end{array}$ & Skewness & Kurtosis \\
\hline Emotional Intelligence Scale & \multicolumn{5}{|l|}{} \\
\hline Emotional Awareness & \multicolumn{5}{|l|}{} \\
\hline $\begin{array}{l}\text { Regulating One's Own } \\
\text { Emotions }\end{array}$ & 215 & 4.2042 & 1.15525 & -1.023 & .422 \\
\hline Internal Motivation & 215 & 4.2287 & 1.18894 & -.905 & .118 \\
\hline Empathy & 215 & 4.2953 & 1.22399 & -1.085 & .460 \\
\hline Regulating Others' Emotions & 215 & 4.2426 & 1.17781 & -1.225 & .921 \\
\hline $\begin{array}{l}\text { Scale of Interpersonal Relationship } \\
\text { Dimensions }\end{array}$ & 215 & 4.2364 & 1.18567 & -1.077 & .560 \\
\hline Approval Dependency & & & & \\
\hline Empathy & 215 & 3.1698 & .50979 & -.956 & 1.106 \\
\hline Trust in Others & 215 & 3.5096 & .75837 & -.648 & .831 \\
\hline Emotional Awareness & 215 & 2.8192 & .50023 & .666 & .733 \\
\hline
\end{tabular}

In Table 3, the mean scores of the sub-dimensions of emotional intelligence and interpersonal relationship dimensions are given. The highest mean score was obtained for the sub-dimension of "Internal Motivation" and the lowest mean score for the sub-dimension of "Emotional Awareness" from among the sub-dimensions of the Emotional Intelligence Scale and the highest mean score was obtained for the sub-dimension of "Empathy" from among the sub-dimensions of the Scale of Interpersonal Relationship Dimensions.

According to George and Mallery (2010), if the skewness and Kurtosis values are between +2.0 and -2.0 and according to Tabachnick and Fidell (2013), if these values are between +1.5 and -1.5 , the scale is considered to be normally distributed and parametric tests are accepted to yield more valid and reliable results. In this connection, as the skewness and Kurtosis values of the scales were found to be between +2.0 and -2.0 , three of the parametric tests, One-Way Anova, independent samples t-test and Pearson correlation analysis were used in the current study.

Table 4. Results of the T-test Conducted to Determine whether the Participants' Level of Emotional Intelligence and Interpersonal Relationship Dimensions Vary Significantly Depending on Gender

\begin{tabular}{|c|c|c|c|c|c|c|c|}
\hline & Dimensions & Groups & $\mathbf{N}$ & $\overline{\mathbf{X}}$ & Ss & $\mathbf{T}$ & $\mathbf{P}$ \\
\hline \multirow{10}{*}{ 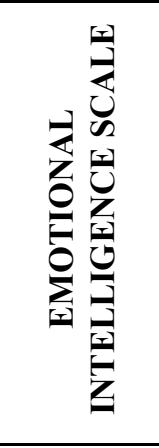 } & \multirow{2}{*}{ Emotional Awareness } & Female & 59 & 3.9051 & 1.25415 & \multirow{2}{*}{-2.359} & \multirow{2}{*}{.019} \\
\hline & & Male & 156 & 4.3173 & 1.09869 & & \\
\hline & \multirow{2}{*}{$\begin{array}{c}\text { Regulating One's Own } \\
\text { Emotions }\end{array}$} & Female & 59 & 3.9181 & 1.33023 & \multirow{2}{*}{-2.381} & \multirow{2}{*}{.018} \\
\hline & & Male & 156 & 4.3462 & 1.11306 & & \\
\hline & \multirow{2}{*}{ Internal Motivation } & Female & 59 & 3.9718 & 1.26557 & \multirow[b]{2}{*}{-2.411} & \multirow[b]{2}{*}{.017} \\
\hline & & Male & 156 & 4.4177 & 1.18918 & & \\
\hline & \multirow{2}{*}{ Empathy } & Female & 59 & 4.0621 & 1.42464 & \multirow{2}{*}{-1.385} & \multirow{2}{*}{.168} \\
\hline & & Male & 156 & 4.3109 & 1.06712 & & \\
\hline & \multirow{2}{*}{$\begin{array}{l}\text { Regulating Others' } \\
\text { Emotions }\end{array}$} & Female & 59 & 3.9802 & 1.28582 & \multirow{2}{*}{-1.961} & \multirow{2}{*}{.051} \\
\hline & & Male & 156 & 4.3333 & 1.13482 & & \\
\hline \multirow{4}{*}{$\underbrace{}_{\mathscr{U}}$} & \multirow{2}{*}{ Approval Dependency } & Female & 59 & 3.1695 & .48120 & \multirow{2}{*}{-.005} & \multirow{2}{*}{.996} \\
\hline & & Male & 156 & 3.1699 & .52170 & & \\
\hline & \multirow{2}{*}{ Empathy } & Female & 59 & 3.5666 & .70485 & \multirow{2}{*}{.676} & \multirow{2}{*}{.500} \\
\hline & & Male & 156 & 3.4881 & .77874 & & \\
\hline
\end{tabular}




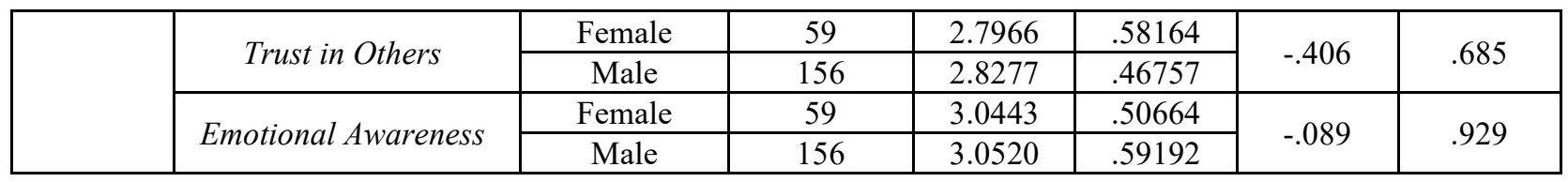

In Table 4, the results of the t-test conducted to determine whether the participants' level of emotional intelligence and interpersonal relationship dimensions vary significantly depending on gender are presented. When the results of the analysis are examined, it is seen that the mean scores taken from the sub-dimensions of Emotional Awareness, Regulating One's Own Emotions and Internal Motivation in the Emotional Intelligence Scale vary significantly depending on gender $(\mathrm{p}<0.05)$. In other words, the mean scores of the male pilots taken from the sub-dimensions of emotional awareness, regulating one's own emotions and internal motivation are significantly higher than those of the female pilots. On the other hand, the mean scores taken for sub-dimensions of Approval Dependency, Empathy, Trust in Others, Emotional Awareness in the Scale of Interpersonal Relationship Dimensions were found to be not varying significantly depending on gender ( $p>0.05)$. In other words, the male and female pilots' levels of interpersonal relationships are similar.

Table 5. Results of the T-test Conducted to Determine whether the Participants' Level of Emotional Intelligence and Interpersonal Relationship Dimensions Vary Significantly Depending on Marital Status

\begin{tabular}{|c|c|c|c|c|c|c|c|}
\hline & Dimensions & Groups & $\mathbf{N}$ & $\overline{\mathbf{X}}$ & Ss & $\mathbf{T}$ & $\mathbf{P}$ \\
\hline \multirow{10}{*}{ 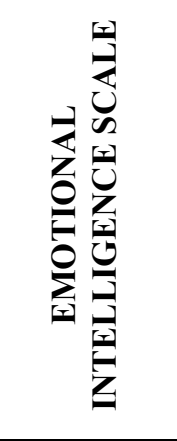 } & \multirow[b]{2}{*}{ Emotional Awareness } & Married & 89 & 4.3303 & 1.06647 & \multirow[b]{2}{*}{1.348} & \multirow[b]{2}{*}{.179} \\
\hline & & Single & 126 & 4.1151 & 1.21029 & & \\
\hline & \multirow{2}{*}{$\begin{array}{l}\text { Regulating One's } \\
\text { Own Emotions }\end{array}$} & Married & 89 & 4.3127 & 1.07392 & \multirow{2}{*}{.871} & \multirow{2}{*}{.385} \\
\hline & & Single & 126 & 4.1693 & 1.26473 & & \\
\hline & \multirow{2}{*}{ Internal Motivation } & Married & 89 & 4.3371 & 1.13401 & \multirow{2}{*}{.419} & \multirow{2}{*}{.675} \\
\hline & & Single & 126 & 4.2659 & 1.28741 & & \\
\hline & \multirow{2}{*}{ Empathy } & Married & 89 & 4.3109 & 1.06339 & \multirow{2}{*}{.713} & \multirow{2}{*}{.477} \\
\hline & & Single & 126 & 4.1944 & 1.25428 & & \\
\hline & \multirow{2}{*}{$\begin{array}{c}\text { Regulating Others' } \\
\text { Emotions }\end{array}$} & Married & 89 & 4.2715 & 1.09302 & \multirow{2}{*}{.364} & \multirow{2}{*}{.716} \\
\hline & & Single & 126 & 4.2116 & 1.25067 & & \\
\hline \multirow{8}{*}{ 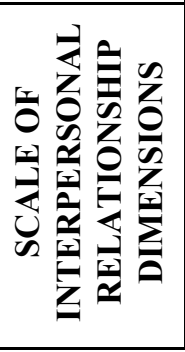 } & \multirow{2}{*}{$\begin{array}{c}\text { Approval } \\
\text { Dependency }\end{array}$} & Married & 89 & 3.2219 & .46723 & \multirow{2}{*}{1.262} & \multirow{2}{*}{.208} \\
\hline & & Single & 126 & 3.1329 & .53660 & & \\
\hline & \multirow{2}{*}{ Empathy } & Married & 89 & 3.5746 & .64068 & \multirow{2}{*}{1.057} & \multirow{2}{*}{.292} \\
\hline & & Single & 126 & 3.4637 & .83097 & & \\
\hline & \multirow{2}{*}{ Trust in Others } & Married & 89 & 2.7949 & .46704 & \multirow{2}{*}{-.596} & \multirow{2}{*}{.552} \\
\hline & & Single & 126 & 2.8363 & .52356 & & \\
\hline & \multirow{2}{*}{ Emotional Awareness } & Married & 89 & 3.0811 & .61859 & \multirow{2}{*}{.677} & \multirow{2}{*}{.499} \\
\hline & & Single & 126 & 3.0278 & .53198 & & \\
\hline
\end{tabular}

In Table 5, the results of the t-test conducted to determine whether the participants' level of emotional intelligence and interpersonal relationship dimensions vary significantly depending on the marital status are presented. When the results of the analysis are examined, it is seen that the mean scores taken from the sub-dimensions of Emotional Awareness, Regulating One's Own Emotions, Internal Motivation, Empathy and Regulating Others' Emotions in the Scale of Emotional Intelligence and the mean scores taken from the sub-dimensions of Approval Dependency, Empathy, Trust in Others and Emotional Awareness in the Scale of Interpersonal Relationship Dimensions do not vary significantly depending on marital status ( $>0.05$ ). In other words, the married and single pilots' levels of emotional intelligence and interpersonal relationships are similar. 
SAFARLI, Elnaz - The Importance of Emotional Intelligence in Interpersonal Relationships: A Study on Pilots in the Context of Daniel Goleman's Emotional Intelligence Model

Table 6. Results of the T-test Conducted to Determine whether the Participants' Level of Emotional Intelligence and Interpersonal Relationship Dimensions Vary Significantly Depending on Position

\begin{tabular}{|c|c|c|c|c|c|c|c|}
\hline & & & & & & \multirow{2}{*}{\multicolumn{2}{|c|}{ D }} \\
\hline & Dimensions & Groups & $\mathbf{N}$ & $\overline{\mathbf{X}}$ & Ss & & \\
\hline \multirow{10}{*}{ 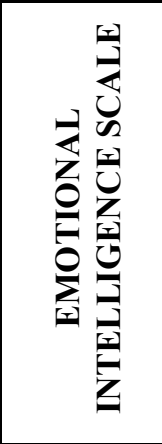 } & \multirow{2}{*}{$\begin{array}{l}\text { Emotional } \\
\text { Awareness }\end{array}$} & Chief Pilot (Pilot in Command) & 75 & 4.1013 & 1.16960 & \multirow[b]{2}{*}{-.955} & \multirow[b]{2}{*}{.341} \\
\hline & & First Officer & 140 & 4.2593 & 1.14790 & & \\
\hline & \multirow{2}{*}{\begin{tabular}{|l} 
Regulating One's \\
Own Emotions
\end{tabular}} & Chief Pilot (Pilot in Command) & 75 & 3.9978 & 1.17994 & \multirow[b]{2}{*}{-2.101} & \multirow{2}{*}{.037} \\
\hline & & First Officer & 140 & 4.3524 & 1.17937 & & \\
\hline & \multirow{2}{*}{$\begin{array}{c}\text { Internal } \\
\text { Motivation }\end{array}$} & Chief Pilot (Pilot in Command) & 75 & 4.1200 & 1.21476 & \multirow{2}{*}{-1.542} & \multirow{2}{*}{.124} \\
\hline & & First Officer & 140 & 4.3893 & 1.22289 & & \\
\hline & \multirow{2}{*}{ Empathy } & Chief Pilot (Pilot in Command) & 75 & 4.1378 & 1.18783 & \multirow{2}{*}{-.955} & \multirow{2}{*}{.341} \\
\hline & & First Officer & 140 & 4.2988 & 1.17282 & & \\
\hline & \multirow{2}{*}{$\begin{array}{c}\text { Regulating } \\
\text { Others' Emotions }\end{array}$} & Chief Pilot (Pilot in Command) & 75 & 4.2000 & 1.26604 & \multirow{2}{*}{-.329} & \multirow{2}{*}{.742} \\
\hline & & First Officer & 140 & 4.2560 & 1.14452 & & \\
\hline \multirow{8}{*}{ 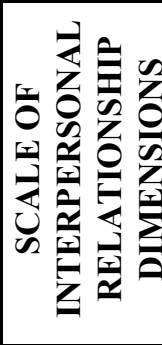 } & \multirow{2}{*}{$\begin{array}{c}\text { Approval } \\
\text { Dependency }\end{array}$} & Chief Pilot (Pilot in Command) & 75 & 3.2650 & .44833 & \multirow[b]{2}{*}{2.019} & \multirow{2}{*}{.045} \\
\hline & & First Officer & 140 & 3.1188 & .53441 & & \\
\hline & \multirow{2}{*}{ Empathy } & Chief Pilot (Pilot in Command) & 75 & 3.4114 & .82833 & \multirow{2}{*}{-1.393} & \multirow{2}{*}{.165} \\
\hline & & First Officer & 140 & 3.5622 & .71566 & & \\
\hline & \multirow{2}{*}{ Trust in Others } & Chief Pilot (Pilot in Command) & 75 & 2.8083 & .44662 & \multirow{2}{*}{-.232} & \multirow{2}{*}{.817} \\
\hline & & First Officer & 140 & 2.8250 & .52816 & & \\
\hline & \multirow{2}{*}{$\begin{array}{l}\text { Emotional } \\
\text { Awareness }\end{array}$} & Chief Pilot (Pilot in Command) & 75 & 2.9778 & .36396 & \multirow{2}{*}{-1.363} & \multirow{2}{*}{.174} \\
\hline & & First Officer & 140 & 3.0885 & .65038 & & \\
\hline
\end{tabular}

In Table 6, the results of the t-test conducted to determine whether the participants' level of emotional intelligence and interpersonal relationship dimensions vary significantly depending on the position are presented. When the results of the analysis are examined, it is seen that the mean scores taken from the sub-dimension of Regulating One's Own Emotion in the Emotional Intelligence Scale and the sub-dimension of Approval Dependency in the Scale of Interpersonal Relationship Dimensions vary significantly depending on the position of the pilots $(p<0.05)$. In other words, the first officers' level of approval dependency is lower than that of the chief pilots and the chief pilots' level of regulating their own emotions is lower than that of the first officers. No significant difference based on the position of the pilots was found in the other sub-dimensions of the Emotional Intelligence Scale and the Scale of Interpersonal Relationship Dimensions ( $p>0.05)$.

Table 7. Results of the ANOVA Conducted to Determine whether the Participants' Level of Emotional Intelligence and Interpersonal Relationship Dimensions Vary Significantly Depending on Age

\begin{tabular}{|c|c|c|c|c|c|c|c|}
\hline & Dimensions & Groups & $\mathbf{N}$ & $\overline{\mathbf{X}}$ & Ss & $\mathbf{F}$ & $\mathbf{P}$ \\
\hline \multirow{15}{*}{ 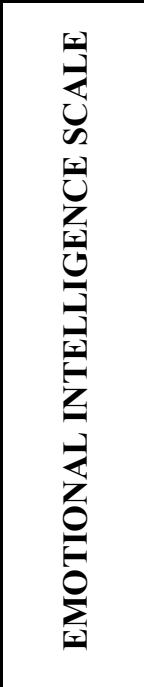 } & \multirow{3}{*}{$\begin{array}{c}\text { Emotional Awareness } \\
\text { Regulating One's Own } \\
\text { Emotions }\end{array}$} & $21-28$ & 70 & 4.2600 & 1.14277 & \multirow{3}{*}{.389} & \multirow{3}{*}{.679} \\
\hline & & $28-34$ & 97 & 4.2268 & 1.12791 & & \\
\hline & & 35 and older & 48 & 4.0771 & 1.24049 & & \\
\hline & \multirow{3}{*}{ Internal Motivation } & $21-28$ & 70 & 4.2524 & 1.19201 & \multirow{3}{*}{.204} & \multirow{3}{*}{.816} \\
\hline & & $28-34$ & 97 & 4.2595 & 1.13140 & & \\
\hline & & 35 and older & 48 & 4.1319 & 1.31277 & & \\
\hline & \multirow{3}{*}{$\begin{array}{c}\text { Empathy } \\
\text { Regulating Others' } \\
\text { Emotions }\end{array}$} & $21-28$ & 70 & 4.2643 & 1.19866 & \multirow{3}{*}{.164} & \multirow{3}{*}{.849} \\
\hline & & $28-34$ & 97 & 4.3471 & 1.18894 & & \\
\hline & & 35 and older & 48 & 4.2361 & 1.34693 & & \\
\hline & \multirow{3}{*}{ Emotional Awareness } & $21-28$ & 70 & 4.3167 & 1.13222 & \multirow{3}{*}{.253} & \multirow{3}{*}{.777} \\
\hline & & $28-34$ & 97 & 4.2285 & 1.07672 & & \\
\hline & & 35 and older & 48 & 4.1632 & 1.43227 & & \\
\hline & \multirow{3}{*}{$\begin{array}{c}\text { Regulating One's Own } \\
\text { Emotions }\end{array}$} & $21-28$ & 70 & 4.3548 & 1.13817 & \multirow{3}{*}{.804} & \multirow{3}{*}{.449} \\
\hline & & $28-34$ & 97 & 4.2320 & 1.06190 & & \\
\hline & & 35 and older & 48 & 4.0729 & 1.46548 & & \\
\hline \multirow{5}{*}{ 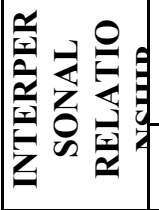 } & \multirow{3}{*}{ Approval Dependency } & $21-28$ & 70 & 3.1071 & .49922 & \multirow{3}{*}{.803} & \multirow{3}{*}{.449} \\
\hline & & $28-34$ & 97 & 3.2062 & .50680 & & \\
\hline & & 35 and older & 48 & 3.1875 & .53283 & & \\
\hline & \multirow{2}{*}{ Empathy } & $21-28$ & 70 & 3.3184 & .93509 & \multirow{2}{*}{5.532} & \multirow{2}{*}{.005} \\
\hline & & $28-34$ & 97 & 3.6907 & .56382 & & \\
\hline
\end{tabular}




\begin{tabular}{|c|c|c|c|c|c|c|}
\hline & 35 and older & 48 & 3.4226 & .74549 & & \\
\hline \multirow{3}{*}{ Trust in Others } & $21-28$ & 70 & 2.9143 & .56488 & \multirow{3}{*}{1.907} & \multirow{3}{*}{.151} \\
\hline & $28-34$ & 97 & 2.7784 & .43283 & & \\
\hline & 35 and older & 48 & 2.7630 & .51779 & & \\
\hline \multirow{3}{*}{ Emotional Awareness } & $21-28$ & 70 & 3.0786 & .51010 & \multirow{3}{*}{.133} & \multirow{3}{*}{.876} \\
\hline & $28-34$ & 97 & 3.0378 & .50407 & & \\
\hline & 35 and older & 48 & 3.0324 & .75462 & & \\
\hline
\end{tabular}

In Table 7, the results of the ANOVA conducted to determine whether the participants' level of emotional intelligence and interpersonal relationship dimensions vary significantly depending on gender are presented. When the results of the one-way ANOVA test are examined, it is seen that the mean scores taken from the subdimensions of Emotional Awareness, Regulating One's Own Emotions, Internal Motivation, Empathy and Regulating Others' Emotions in the Emotional Intelligence Scale and from the sub-dimensions of Approval Dependency, Trust in Others and Emotional Awareness in the Scale of Interpersonal Relationship Dimensions do not vary significantly depending on age $(\mathrm{p}>0.05)$. In other words, the emotional intelligence levels and interpersonal relationship levels of the pilots from different age groups are similar. However, the mean scores taken from the sub-dimension of empathy in the Emotional Intelligence Scale do not vary significantly depending on age $(\mathrm{p}<0.05)$.

Table 8. Results of the ANOVA Conducted to Determine whether the Participants' Level of Emotional Intelligence and Interpersonal Relationship Dimensions Vary Significantly Depending on Length of Service

\begin{tabular}{|c|c|c|c|c|c|c|c|}
\hline & Dimensions & Groups & $\mathbf{N}$ & $\overline{\mathbf{X}}$ & Ss & $\mathbf{F}$ & $\mathbf{P}$ \\
\hline \multirow{15}{*}{ 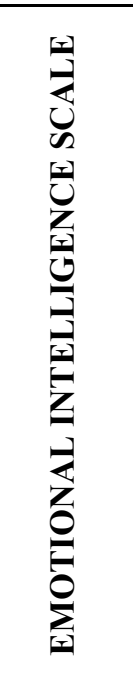 } & \multirow{3}{*}{$\begin{array}{c}\text { Emotional Awareness } \\
\text { Regulating One's Own } \\
\text { Emotions }\end{array}$} & $0-6$ years & 119 & 4.3454 & 1.12406 & \multirow{3}{*}{2.451} & \multirow{3}{*}{.089} \\
\hline & & $7-12$ years & 62 & 3.9484 & 1.21355 & & \\
\hline & & 13 and longer & 34 & 4.1765 & 1.10400 & & \\
\hline & \multirow{3}{*}{ Internal Motivation } & $0-6$ years & 119 & 4.4636 & 1.13333 & \multirow{3}{*}{5.768} & \multirow{3}{*}{.004} \\
\hline & & $7-12$ years & 62 & 3.8656 & 1.22431 & & \\
\hline & & 13 and longer & 34 & 4.0686 & 1.15333 & & \\
\hline & \multirow{3}{*}{$\begin{array}{c}\text { Empathy } \\
\text { Regulating Others, } \\
\text { Emotions }\end{array}$} & $0-6$ years & 119 & 4.4846 & 1.17771 & \multirow{3}{*}{3.670} & \multirow{3}{*}{.027} \\
\hline & & $7-12$ years & 62 & 3.9785 & 1.39394 & & \\
\hline & & 13 and longer & 34 & 4.2108 & .91592 & & \\
\hline & \multirow{3}{*}{ Emotional Awareness } & $0-6$ years & 119 & 4.3866 & 1.07465 & \multirow{3}{*}{2.651} & \multirow{3}{*}{.073} \\
\hline & & $7-12$ years & 62 & 3.9651 & 1.34832 & & \\
\hline & & 13 and longer & 34 & 4.2451 & 1.13428 & & \\
\hline & \multirow{3}{*}{$\begin{array}{c}\text { Regulating One's Own } \\
\text { Emotions }\end{array}$} & $0-6$ years & 119 & 4.3711 & 1.08652 & \multirow{3}{*}{2.090} & \multirow{3}{*}{.126} \\
\hline & & $7-12$ years & 62 & 3.9946 & 1.35433 & & \\
\hline & & 13 and longer & 34 & 4.2059 & 1.15255 & & \\
\hline \multirow{12}{*}{ 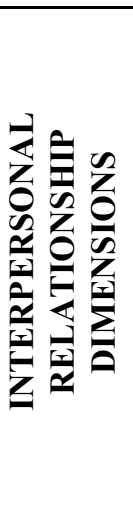 } & \multirow{3}{*}{ Approval Dependency } & $0-6$ years & 119 & 3.0599 & .56370 & \multirow{3}{*}{6.629} & \multirow{3}{*}{.002} \\
\hline & & $7-12$ years & 62 & 3.2883 & .39760 & & \\
\hline & & 13 and longer & 34 & 3.3382 & .39711 & & \\
\hline & \multirow{3}{*}{ Empathy } & $0-6$ years & 119 & 3.4562 & .81415 & \multirow{3}{*}{.844} & \multirow{3}{*}{.431} \\
\hline & & $7-12$ years & 62 & 3.6106 & .71131 & & \\
\hline & & 13 and longer & 34 & 3.5126 & .62825 & & \\
\hline & \multirow{3}{*}{ Trust in Others } & $0-6$ years & 119 & 2.9139 & .55990 & \multirow{3}{*}{5.141} & \multirow{3}{*}{.007} \\
\hline & & $7-12$ years & 62 & 2.6794 & .37440 & & \\
\hline & & 13 and longer & 34 & 2.7426 & .40934 & & \\
\hline & \multirow{3}{*}{ Emotional Awareness } & $0-6$ years & 119 & 3.1545 & .60902 & \multirow{3}{*}{4.955} & \multirow{3}{*}{.008} \\
\hline & & $7-12$ years & 62 & 2.8889 & .43802 & & \\
\hline & & 13 and longer & 34 & 2.9771 & .56773 & & \\
\hline
\end{tabular}

In Table 8, the results of the ANOVA conducted to determine whether the participants' level of emotional intelligence and interpersonal relationship dimensions vary significantly depending on the length of service are presented. When the results of the one-way ANOVA test are examined, it is seen that the mean scores taken from the sub-dimensions of Regulating One's Own Emotions and Internal Motivation in the Emotional Intelligence Scale and the sub-dimensions of Approval Dependency, Trust in Others and Emotional Awareness in the Scale of Interpersonal Relationship Dimensions vary significantly depending on the length of service $(p<0.05)$. In other 
SAFARLI, Elnaz - The Importance of Emotional Intelligence in Interpersonal Relationships: A Study on Pilots in the Context of Daniel Goleman's Emotional Intelligence Model

words, when the results of the Post HOC Tukey test are examined, it is seen that while the mean scores of the pilots with the professional experience of 0-6 years taken from the sub-dimensions of regulating their own emotions, internal motivation, trust in others and emotional awareness are significantly higher than those of the pilots having the other lengths of service, their mean score taken from the sub-dimension of approval dependency is lower. No significant difference based on the length of service was found in the other dimensions of the Emotional Intelligence Scale and the Scale of Interpersonal Relationship Dimensions ( $p>0.05)$.

Table 9. Results of the ANOVA Conducted to Determine whether the Participants' Level of Emotional Intelligence and Interpersonal Relationship Dimensions Vary Significantly Depending on Where They Work

\begin{tabular}{|c|c|c|c|c|c|c|c|}
\hline & Dimensions & Groups & $\mathbf{N}$ & $\overline{\mathbf{X}}$ & Ss & $\mathbf{F}$ & $\mathbf{P}$ \\
\hline \multirow{15}{*}{ 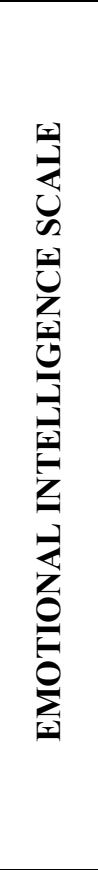 } & \multirow{3}{*}{$\begin{array}{l}\text { Emotional } \\
\text { Awareness }\end{array}$} & Domestic Airlines & 80 & 4.4175 & 1.00288 & \multirow{3}{*}{2.214} & \multirow{3}{*}{.112} \\
\hline & & International Airlines & 49 & 4.0531 & 1.05180 & & \\
\hline & & $\begin{array}{l}\text { Others (flying school or other } \\
\text { organizations) }\end{array}$ & 86 & 4.0919 & 1.31598 & & \\
\hline & \multirow{3}{*}{$\begin{array}{c}\text { Regulating } \\
\text { One's Own } \\
\text { Emotions }\end{array}$} & Domestic Airlines & 80 & 4.4542 & 1.01465 & \multirow{3}{*}{2.868} & \multirow{3}{*}{.059} \\
\hline & & International Airlines & 49 & 3.9558 & 1.04736 & & \\
\hline & & $\begin{array}{l}\text { Others (flying school or other } \\
\text { organizations) }\end{array}$ & 86 & 4.1744 & 1.37435 & & \\
\hline & \multirow{3}{*}{$\begin{array}{l}\text { Internal } \\
\text { Motivation }\end{array}$} & Domestic Airlines & 80 & 4.5729 & 1.03621 & \multirow{3}{*}{5.161} & \multirow{3}{*}{.006} \\
\hline & & International Airlines & 49 & 3.8741 & 1.10477 & & \\
\hline & & $\begin{array}{c}\text { Others (flying school or other } \\
\text { organizations) }\end{array}$ & 86 & 4.2771 & 1.38186 & & \\
\hline & \multirow{3}{*}{ Empathy } & Domestic Airlines & 80 & 4.5167 & .94564 & \multirow{3}{*}{3.555} & \multirow{3}{*}{.030} \\
\hline & & International Airlines & 49 & 4.0510 & 1.08983 & & \\
\hline & & $\begin{array}{l}\text { Others (flying school or other } \\
\text { organizations) }\end{array}$ & 86 & 4.0969 & 1.37019 & & \\
\hline & \multirow{3}{*}{$\begin{array}{c}\text { Regulating } \\
\text { Others } \\
\text { Emotions }\end{array}$} & Domestic Airlines & 80 & 4.5625 & 1.03197 & \multirow{3}{*}{5.062} & \multirow{3}{*}{.007} \\
\hline & & International Airlines & 49 & 3.9966 & 1.10998 & & \\
\hline & & $\begin{array}{l}\text { Others (flying school or other } \\
\text { organizations) }\end{array}$ & 86 & 4.0698 & 1.30095 & & \\
\hline \multirow{12}{*}{ 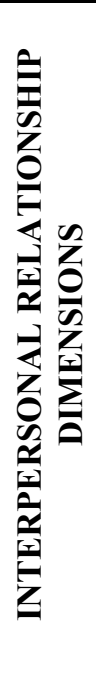 } & \multirow{3}{*}{$\begin{array}{c}\text { Approval } \\
\text { Dependency }\end{array}$} & Domestic Airlines & 80 & 3.1516 & .39262 & \multirow{3}{*}{2.547} & \multirow{3}{*}{.081} \\
\hline & & International Airlines & 49 & 3.3087 & .38367 & & \\
\hline & & $\begin{array}{c}\text { Others (flying school or other } \\
\text { organizations) }\end{array}$ & 86 & 3.1076 & .64231 & & \\
\hline & \multirow{3}{*}{ Empathy } & Domestic Airlines & 80 & 3.3482 & .81254 & \multirow{3}{*}{3.066} & \multirow{3}{*}{.049} \\
\hline & & International Airlines & 49 & 3.5627 & .64114 & & \\
\hline & & $\begin{array}{l}\text { Others (flying school or other } \\
\text { organizations) }\end{array}$ & 86 & 3.6296 & .74935 & & \\
\hline & \multirow{3}{*}{$\begin{array}{l}\text { Trust in } \\
\text { Others }\end{array}$} & Domestic Airlines & 80 & 2.8344 & .41803 & \multirow{3}{*}{.216} & \multirow{3}{*}{.806} \\
\hline & & International Airlines & 49 & 2.7781 & .43992 & & \\
\hline & & $\begin{array}{c}\text { Others (flying school or other } \\
\text { organizations) }\end{array}$ & 86 & 2.8285 & .59750 & & \\
\hline & \multirow{3}{*}{$\begin{array}{l}\text { Emotional } \\
\text { Awareness }\end{array}$} & Domestic Airlines & 80 & 3.0549 & .39408 & \multirow{3}{*}{9.984} & \multirow{3}{*}{.000} \\
\hline & & International Airlines & 49 & 2.7687 & .42361 & & \\
\hline & & $\begin{array}{l}\text { Others (flying school or other } \\
\text { organizations) }\end{array}$ & 86 & 3.2054 & .70593 & & \\
\hline
\end{tabular}

In Table 9, the results of the ANOVA conducted to determine whether the participants' level of emotional intelligence and interpersonal relationship dimensions vary significantly depending on where they work are presented. When the results of the one-way ANOVA test are examined, it is seen that the mean scores taken from the sub-dimensions of Empathy, Internal Motivation, Regulating Others' Emotions in the Emotional Intelligence Scale and the sub-dimensions of Empathy and Emotional Awareness in the Scale of Interpersonal Relationship Dimensions vary significantly depending on where they work $(\mathrm{p}<0.05)$. In other words, when the results of the Post HOC Tukey test are examined, it is seen that the level of emotional intelligence of the pilots working in domestic airlines is significantly higher than that of the pilots working in international airlines and others while their level of interpersonal relationships is lower. However, no significant difference based on where they work 
was found for the other sub-dimensions of the Emotional Intelligence Scale and the Scale of Interpersonal Relationship Dimensions ( $>00.05$ ).

Table 10. Results of the ANOVA Conducted to Determine whether the Participants' Level of Emotional Intelligence and Interpersonal Relationship Dimensions Vary Significantly Depending on Education Level

\begin{tabular}{|c|c|c|c|c|c|c|c|}
\hline & Dimensions & Groups & $\mathbf{N}$ & $\overline{\mathbf{X}}$ & Ss & $\mathbf{F}$ & $\mathbf{P}$ \\
\hline \multirow{20}{*}{ 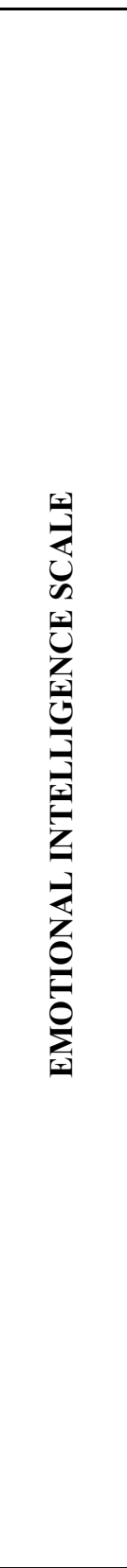 } & \multirow{4}{*}{$\begin{array}{l}\text { Emotional } \\
\text { Awareness }\end{array}$} & $\begin{array}{l}\text { High School (Science } \\
\text { High School) }\end{array}$ & 41 & 3.9463 & 1.12163 & \multirow{4}{*}{1.806} & \multirow{4}{*}{.147} \\
\hline & & $\begin{array}{c}\text { High School (Social } \\
\text { Sciences High School) }\end{array}$ & 50 & 4.1560 & 1.25668 & & \\
\hline & & $\begin{array}{l}\text { University (Pilotage and } \\
\text { related departments) }\end{array}$ & 72 & 4.1778 & 1.11510 & & \\
\hline & & $\begin{array}{l}\text { University (other } \\
\text { departments) }\end{array}$ & 52 & 4.4904 & 1.10671 & & \\
\hline & \multirow{4}{*}{$\begin{array}{l}\text { Regulating } \\
\text { One's Own } \\
\text { Emotions }\end{array}$} & $\begin{array}{l}\text { High School (Science } \\
\text { High School) }\end{array}$ & 41 & 3.9228 & 1.24839 & \multirow{4}{*}{1.798} & \multirow{4}{*}{.149} \\
\hline & & $\begin{array}{c}\text { High School (Social } \\
\text { Sciences High School) }\end{array}$ & 50 & 4.1967 & 1.24435 & & \\
\hline & & $\begin{array}{c}\text { University (Pilotage and } \\
\text { related departments) }\end{array}$ & 72 & 4.2338 & 1.09261 & & \\
\hline & & $\begin{array}{c}\text { University (other } \\
\text { departments) }\end{array}$ & 52 & 4.4936 & 1.18816 & & \\
\hline & \multirow{4}{*}{$\begin{array}{l}\text { Internal } \\
\text { Motivation }\end{array}$} & $\begin{array}{c}\text { High School (Science } \\
\text { High School) }\end{array}$ & 41 & 3.9024 & 1.20299 & \multirow{4}{*}{2.313} & \multirow{4}{*}{.077} \\
\hline & & $\begin{array}{c}\text { High School (Social } \\
\text { Sciences High School) }\end{array}$ & 50 & 4.3067 & 1.30513 & & \\
\hline & & $\begin{array}{l}\text { University (Pilotage and } \\
\text { related departments) }\end{array}$ & 72 & 4.3148 & 1.18894 & & \\
\hline & & $\begin{array}{c}\text { University (other } \\
\text { departments) }\end{array}$ & 52 & 4.5673 & 1.16047 & & \\
\hline & \multirow{4}{*}{ Empathy } & $\begin{array}{c}\text { High School (Science } \\
\text { High School) }\end{array}$ & 41 & 3.9553 & 1.22249 & \multirow{4}{*}{1.239} & \multirow{4}{*}{.297} \\
\hline & & $\begin{array}{l}\text { High School (Social } \\
\text { Sciences High School) }\end{array}$ & 50 & 4.2500 & 1.28097 & & \\
\hline & & $\begin{array}{l}\text { University (Pilotage and } \\
\text { related departments) }\end{array}$ & 72 & 4.2708 & 1.10038 & & \\
\hline & & $\begin{array}{l}\text { University (other } \\
\text { departments) }\end{array}$ & 52 & 4.4231 & 1.13398 & & \\
\hline & \multirow{4}{*}{$\begin{array}{l}\text { Regulating } \\
\text { Others' } \\
\text { Emotions }\end{array}$} & $\begin{array}{l}\text { High School (Science } \\
\text { High School) }\end{array}$ & 41 & 4.1138 & 1.22556 & \multirow{4}{*}{.963} & \multirow{4}{*}{.411} \\
\hline & & $\begin{array}{l}\text { High School (Social } \\
\text { Sciences High School) }\end{array}$ & 50 & 4.0633 & 1.25306 & & \\
\hline & & $\begin{array}{l}\text { University (Pilotage and } \\
\text { related departments) }\end{array}$ & 72 & 4.2963 & 1.19212 & & \\
\hline & & $\begin{array}{l}\text { University (other } \\
\text { departments) }\end{array}$ & 52 & 4.4167 & 1.07431 & & \\
\hline \multirow{6}{*}{ 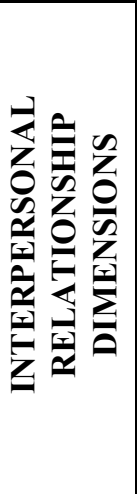 } & \multirow{4}{*}{$\begin{array}{c}\text { Approval } \\
\text { Dependency }\end{array}$} & $\begin{array}{l}\text { High School (Science } \\
\text { High School) }\end{array}$ & 41 & 3.2713 & .42010 & \multirow{4}{*}{3.134} & \multirow{4}{*}{.027} \\
\hline & & $\begin{array}{l}\text { High School (Social } \\
\text { Sciences High School) }\end{array}$ & 50 & 3.2475 & .45631 & & \\
\hline & & $\begin{array}{l}\text { University (Pilotage and } \\
\text { related departments) }\end{array}$ & 72 & 3.1858 & .40026 & & \\
\hline & & $\begin{array}{l}\text { University (other } \\
\text { departments) }\end{array}$ & 52 & 2.9928 & .69461 & & \\
\hline & \multirow{2}{*}{ Empathy } & $\begin{array}{c}\text { High School (Science } \\
\text { High School) }\end{array}$ & 41 & 3.4843 & .80234 & \multirow{2}{*}{2.881} & \multirow{2}{*}{.037} \\
\hline & & $\begin{array}{c}\text { High School (Social } \\
\text { Sciences High School) }\end{array}$ & 50 & 3.7486 & .61737 & & \\
\hline
\end{tabular}


SAFARLI, Elnaz - The Importance of Emotional Intelligence in Interpersonal Relationships: A Study on Pilots in the Context of Daniel Goleman's Emotional Intelligence Model

\begin{tabular}{|c|c|c|c|c|c|c|}
\hline & $\begin{array}{l}\text { University (Pilotage and } \\
\text { related departments) }\end{array}$ & 72 & 3.3452 & .73423 & & \\
\hline & $\begin{array}{l}\text { University (other } \\
\text { departments) }\end{array}$ & 52 & 3.5275 & .83469 & & \\
\hline \multirow{4}{*}{$\begin{array}{l}\text { Trust in } \\
\text { Others }\end{array}$} & $\begin{array}{c}\text { High School (Science } \\
\text { High School) }\end{array}$ & 41 & 2.8110 & .35258 & \multirow{4}{*}{2.390} & \multirow{4}{*}{.070} \\
\hline & $\begin{array}{c}\text { High School (Social } \\
\text { Sciences High School) }\end{array}$ & 50 & 2.7175 & .51866 & & \\
\hline & $\begin{array}{c}\text { University (Pilotage and } \\
\text { related departments) }\end{array}$ & 72 & 2.7865 & .44328 & & \\
\hline & $\begin{array}{l}\text { University (other } \\
\text { departments) }\end{array}$ & 52 & 2.9688 & .62125 & & \\
\hline \multirow{4}{*}{$\begin{array}{l}\text { Emotional } \\
\text { Awareness }\end{array}$} & $\begin{array}{c}\text { High School (Science } \\
\text { High School) }\end{array}$ & 41 & 2.9946 & .42886 & \multirow{4}{*}{5.339} & \multirow{4}{*}{.001} \\
\hline & $\begin{array}{c}\text { High School (Social } \\
\text { Sciences High School) }\end{array}$ & 50 & 2.9044 & .43180 & & \\
\hline & $\begin{array}{c}\text { University (Pilotage and } \\
\text { related departments) }\end{array}$ & 72 & 2.9954 & .48966 & & \\
\hline & $\begin{array}{l}\text { University (other } \\
\text { departments) }\end{array}$ & 52 & 3.3088 & .77711 & & \\
\hline
\end{tabular}

In Table 10, the results of the ANOVA conducted to determine whether the participants' level of emotional intelligence and interpersonal relationship dimensions vary significantly depending on education level. When the results of the one-way ANOVA test are examined, it is seen that the mean scores are taken from the subdimensions of Emotional Awareness, Regulating One's Own Emotions, Internal Motivation, Empathy and Regulating Others' Emotions in the Emotional Intelligence Scale do not vary significantly depending on education level ( $p>0.05)$. In other words, the emotional intelligence levels of the pilots having different education levels are similar. On the other hand, the mean scores taken from the sub-dimensions of Empathy, Approval Dependency, Emotional Awareness in the Scale of Interpersonal Relationship Dimensions were found to be varying significantly depending on the education level of the pilots $(p<0.05)$. According to the results of the Post HOC test, the level of interpersonal relationships of the pilots who are university graduates (other departments) is higher than that of the pilots with the other levels of education.

Table 11. Relationship between Emotional Intelligence and Interpersonal Relationships

\begin{tabular}{|c|c|c|c|c|}
\hline & $\begin{array}{c}\text { Approval } \\
\text { Dependency }\end{array}$ & Empathy & Trust in Others & $\begin{array}{l}\text { Emotional } \\
\text { Awareness }\end{array}$ \\
\hline Emotional Awareness & $-.257^{* *}$ & $-.256^{* *}$ & $.302^{* *}$ & $.276^{* *}$ \\
\hline Regulating One's Own Emotions & $-.297^{* *}$ & $-.272^{* *}$ & $.230^{* *}$ & $.267^{* *}$ \\
\hline Internal Motivation & $-.310^{* *}$ & $-.311^{* *}$ & $.280^{* *}$ & $.306^{* *}$ \\
\hline Empathy & $-.188^{* *}$ & $-.323^{* *}$ & $.238^{* *}$ & $.210^{* *}$ \\
\hline Regulating Others' Emotions & $-.157^{*}$ & $-.340^{* *}$ & $.281^{* *}$ & $.181^{* *}$ \\
\hline
\end{tabular}

** and * indicate the level of significance at $1 \%$ and $5 \%$, respectively.

The results of the Pearson correlation analysis conducted to determine the relationship between emotional intelligence and interpersonal relationships are presented in Table 11. There is a statistically significant and negative correlation between the sub-dimensions of Emotional Awareness, Regulating One's Own Emotions, Internal Motivation, Empathy and Regulating Others' Emotions in the Emotional Intelligence Scale and the subdimensions of Approval Dependency and Empathy in the Scale of Interpersonal Relationship Dimensions $(p<0.05)$. On the other hand, there is a statistically significant and positive correlation between the sub-dimensions of Trust in Others and Emotional Awareness in the Scale of Interpersonal Relationship Dimensions and the sub- 
dimensions of Emotional Awareness, Regulating One's Own Emotions, Internal Motivation, Empathy and Regulating Others' Emotions in the Emotional Intelligence Scale $(\mathrm{p}<0.05)$.

\section{RESULTS}

In the current study, the relationship between emotional intelligence and interpersonal relationships was examined. It was also determined how the relationship between the pilots' identification, evaluation, use and regulation of their own and others' emotions and interpersonal relationships varies depending on some demographic factors. The study was conducted on a total of 215 pilots.

As a result of the analyses, it was concluded that the pilots' level of emotional intelligence varies significantly depending on gender, length of service, position and where they work. On the other hand, the education level of the pilots was found to have no significant effect on their emotional intelligence. While these findings are parallel to the findings reported by Turgut (2014), they contradict the findings reported by Delice and Odabaş1 (2013). Moreover, the mean emotional intelligence score of the male pilots was found to be higher than that of the female pilots. Similarly, Odabaşı (2013) and Turgut (2014) stated that the emotional intelligence of males is higher than that of females. As a result, the hypothesis H1of the study is supported.

When the results related to interpersonal relationships are examined, it is seen that the pilots' interpersonal relationships vary significantly depending on gender, length of service, position and where they work. As a result, the hypothesis $\mathrm{H} 2$ of the study is supported. Moreover, there is a statistically significant and negative correlation between the sub-dimensions of Emotional Awareness, Regulating One's Own Emotions, Internal Motivation, Empathy and Regulating Others' Emotions in the Emotional Intelligence Scale and the sub-dimensions of Approval Dependency and Empathy in the Scale of Interpersonal Relationship Dimensions. On the other hand, there is a statistically significant and positive correlation between the sub-dimensions of Trust in Others and Emotional Awareness in the Scale of Interpersonal Relationship Dimensions and the sub-dimensions of Emotional Awareness, Regulating One's Own Emotions, Internal Motivation, Empathy and Regulating Others' Emotions in the Emotional Intelligence Scale. As a result, the hypothesis H3 of the study is supported.

Given that emotional intelligence is defined as the ability to monitor one's own emotions and other people's emotions, to recognize these emotions and to use the data obtained from this recognition to shape their thoughts and behaviours, it was expected that there would be a negative correlation between the scores to be taken from the Emotional Intelligence Scale and the sub-dimensions of Approval Dependency and Empathy in the Scale of Interpersonal Relationship Dimensions. Considering that individuals with high emotional intelligence have the ability to recognize the feelings of the other person, understand them correctly, manage them skilfully by using emotional cues and that individuals with high interpersonal sensitivity, on the contrary, are more likely to think that they are neglected or mistreated in their interpersonal relationships, it is highly natural to see a negative correlation between them.

In light of the findings of the current study, the following suggestions can be made for further studies;

- As the current study was conducted on 215 pilots, there is an important limitation in terms of generalizing the results; therefore, future studies can be conducted on larger and different samples.

- Due to the limited amount of research conducted in our country on interpersonal relationships, which have been more strongly emphasized in the literature in recent years, it is thought that it is necessary to conduct research on this important subject.

- There are some limitations of the current study investigating the relationship between emotional intelligence and interpersonal relationships. A questionnaire was used to determine this relationship in the current study. Sampling, scope, responding and measurement errors that can be encountered in any questionnaire study may have also occurred in this study. This restricts the possibility of making some generalizations on the basis of the findings. Moreover, the results of the study can only be interpreted for pilots.

- Although there are many studies on the relationship between emotional intelligence and interpersonal relationships in the international literature, this number is quite low in the national literature. However, the relationship between emotional intelligence and interpersonal relationships cannot be clearly demonstrated because the results of these studies conflict with each other. Therefore, there is a need for future studies to be conducted on larger samples and with different methods. 


\section{REFERENCES}

BRADBERRY, T., \& GREAVES, J. (2017), “Duygusal Zekâ 2.0”, (A. Ulaş, Çev.) İstanbul: Sola Yayınları.

CARUSO, D. R., \& Salovey, P. (2007), Yönetimde Duygusal Zekâ”, (S. Kaymak, Çev.) İstanbul: Crea Yayıncilık.

ERGINN E.F. (2000), “Üniversite Öğrencilerinin Sahip Oldukları Duygusal Zeka Düzeyi İle 16 Kişilik Özelliliği Arasındaki İlişki Üzerine Bir Araştırma”. Çocuk Gelişimi ve Eğitimi Bilim Dalı Yüksek Lisans Tezi, Selçuk Üniv. Sosyal Bil. Enst. Konya.

GEORGE, D., and MALLERY, M., (2010), "SPSS for Windows Step by Step: A Simple Guide and Reference", Boston.

GOLEMAN, D. (2003), “Duygusal Zekâ", (B. S. Yüksel, Çev.) İstanbul: Varlık Yayınları.

İMAMOĞLU, E.-S. \& AYDIN, B. (2009), "Kişilerarası İlişki Boyutları Ölçeğinin Geliştirilmesi”, Psikoloji Çalışmaları Dergisi, Cilt 29, Sayı 29, 39-64.

ODABAŞI, B. (2013), "İlköğretim 2. Kademe Öğrencilerinin Duygusal Zekâ Düzeylerinin Ana - Baba Tutumları Açısından İncelenmesi”, Anadolu Journal of Educational Sciences International 3(2).

TABACHNICK, B.G., Fidell, L.S. (2013), "Using Multivariate Statistics”, Boston: Pearson.

TARHAN, N. (2017), "Duyguların Psikolojisi ve Duygusal Zekâa”, İstanbul: Timaş Yayınları.

TURGUT, G. (2014), “Algilanan Sosyal Destek Ve Duygusal Zekâ Düzeyinin İs Tatminine Etkisinin Devlette Çalışan Üç Farklı Meslek Grubunda Karşılaştırılması: Mühendis, Doktor Ve Öğretmen”, Maltepe Üniversitesi Sosyal Bilimler Enstitüsü Psikoloji Anabilim Dalı, Yayınlanmamış Yüksek Lisans Tezi.

YAN, İ. (2008), "Duygu-Zekâ İlişkisi ve Duygusal Zekânın Yöneticiler Üzerindeki Etkilerine Yönelik Bir Araştırma", Afyon: Afyon Kocatepe Üniversitesi Sosyal Bilimler Enstitüsü. 